\title{
MODEL PEMBELAJARAN BAHASA DAN SASTRA INDONESIA BERBASIS KEARIFAN LOKAL
}

\author{
Wina Wulandari \\ Pendidikan Bahasa Indonesia \\ Pascasarjana Universitas Negeri Medan
}

\begin{abstract}
Abstrak
Pembelajaran bahasa dan sastra Indonesia merupakan kegiatan yang penting dalam kehidupan manusia yang mengaitkan antara lingkungan atau budaya sekitar. Pada dasarnya pendidikan merupakan bagian yang sangat penting dan tidak terpisahkan dari perjalanan manusia. Melalui pendidikan, kualitas sumber daya manusia dapat semakin meningkat seiring dengan meningkatnya pendidikan yang diperolehnya. Kualitas tersebut akan sangat dibutuhkan dalam persaingan untuk memperoleh sebuah peran dalam memasuki kehidupan global, untuk meraih kesejahteraan hidup. Di Indonesia sendiri, pendidikan mengalami berbagai macam perubahan yang dapat dilihat dari kurikulum yang argumentasinya lebih kepada kurikulum tersebut perlu diganti karena tidak sesuai dengan zaman atau era yang sedang terjadi sehingga diperlukan suatu pembaharuan. Secara umum tujuan penulisan ini adalah mendeskripsikan model pembelajaran bahasa dan satra Indonesia berbasis kearifan lokal. Materi pembelajaran yang dipilih untuk diajarkan oleh guru dan harus dipelajari siswa hendaknya berisikan pembelajaran yang benar-benar menunjang tercapainya standar kompetensi dan kompetensi dasar. Hasil penelitian yang diperoleh adalah menciptakan pembelajaran yang berbasis kearifan lokal pendidik harus mengetahui tentang hal-hal yang dapat menunjang keberhasilan dalam proses belajar salah satunya yaitu mengetahui pembelajaran dan sumber belajar.
\end{abstract}




\section{A. PENDAHULUAN}

Banyak guru yang beranggapan bahwa pembelajaran memiliki peran penting dalam ruang lingkup pendidikan. Pendidikan merupakan bagian yang sangat penting dan tidak terpisahkan dari perjalanan hidup manusia. Melalui pendidikan, kualitas sumber daya manusia dapat semakin meningkat seiring dengan meningkatnya pendidikan yang diperolehnya. Kualitas tersebut akan sangat dibutuhkan dalam persaingan untuk memperoleh sebuah peran dalam memasuki kehidupan global, untuk meraih kesejahteraan hidup. Dalam hal ini, pemerintah telah memberikan rambu-rambu dalam penyelenggaraan pendidikan di Indonesia melalui berbagai macam kebijakan, antara lain tertuang dalam perundang-undangan.

Undang-Undang Sistem Pendidikan Nasional No. 20 Tahun 2003 Bab II Pasal 3 menyatakan bahwa tujuan pendidikan nasional adalah mengembangkan potensi peserta didik agar menjadi manusia yang beriman dan bertakwa kepada Tuhan Yang Maha Esa, berakhlak mulia, sehat, berilmu, cakap, kreatif, mandiri dan menjadi warga negara yang demokratis dan bertanggung jawab.

Sistem pendidikan nasional dalam abad ke 21 menghadapi berbagai tantangan dalam mempersiapkan generasi penerus bangsa yang berkualitas dan berdaya saing. Pembangunan karakter bangsa merupakan bagian penting dan tidak terpisahkan dari pembangunan nasional. Kebijakan nasional pembangunan karakter bangsa ini disusun sebagai pelaksanaan amanat UU RI No. 17 tahun 2007 tentang Rencana Pembangunan Jangka Panjang Nasional Tahun 2005-2025.

Pembangunan karakter bangsa adalah misi pertama dari delapan misi guna mewujudkan visi pembangunan nasional. Secara eksplisit keberhasilan pembangunan karakter bangsa ditandai dengan terbentuknya karakter bangsa yang tangguh, kompetitif, berakhlak mulia, bermoral, bertoleran, bergotong royong, patriotik, dinamis, berbudaya dan berorientasi iptek berdasarkan pancasila dijiwai oleh iman dan takwa kepada Tuhan Yang Maha Esa (Kemendiknas, 2010).

Kearifan budaya lokal dapat diinternalisasikan dalam pendidikan karena dia memiliki banyak kelebihan. Kelebihan tersebut antara lain sebagai berikut: (1) Kearifan budaya lokal dapat menjadi sarana pembelajaran bagi setiap manusia untuk menjadi orang yang cerdas, pandai, dan bijaksana, (2) Kearifan budaya lokal memiliki nilai-nilai positif untuk ditransformasikan kepada peserta didik guna membentuk kepribadian positif. Sebagaimana Sayuti (2009) mengemukakan bahwa budaya dan potensi lokal itu meniscayakan fungsi yang strategis bagi pembentukan karakter dan identitas. 
Atas dasar hal tersebut, selayaknyalah kearifan budaya lokal diintegrasikan dalam model pembelajaran bahasa dan sastra Indonesia memberi inspirasi bahan pembelajaran yang berfungsi untuk membentuk karakter dan identitas siswa.

Berdasarkan pada uraian tersebut, perlu dilakukan pengujian untuk membuktikan bahwa model pembelajaran bahasa dan sastra Indonesia berbasis kearifan budaya lokal yang berorientasi pendidikan karakter lebih efektif.

Sehubungan dengan itu, masalah Melihat hal ini, maka peneliti tertarik untuk menyusun penulisan dengan memperhatikan permasalahan tersebut maka judulnya penulisan ini adalah “ Model pembelajaran Bahasa dan Satra Indonesia berbasis kearifan lokal. Dalam penulisan ini, peneliti akan mendsekripsikan serta memperhatikan model yang bagaimana implementasikan di sekolah yang harus di kuasai oleh guru atau calon-calon perubahan agar dapat menjadi bekal bagi mereka kedepannya.

\section{B. KAJIAN TEORETIS}

\section{A. Pengertian Model}

Pemahaman model dapat dipahami dengan berbagai macam pengertian yang bermacam-macam. Secara etimologi, model berasal dari bahasa italia yakni modello yang dapat diartikan dari berbagai dimensi, jika dari kata benda maka model diartikan sebagai jenis atau contoh, sedangkan dari kata sifat dapat dipahami sebagai teladang atau di ambil sebagai contoh dan yang terakhir dari kata kerja dipahami sebagai membuat dengan contoh. Dengan kata lain, model secara etimologi yakni sesuatu contoh. Dalam kamus besar bahasa indoneis (KBBI), model didefinisikan sebagai pola dari sesuatu yang dibuat atau yang dihasilkan atau barang tiruan. Maka dapat diambil kesimpulan, jika model dapat dipahami sebagai suatu jenis contoh dari suatu pola ( contoh, acuan, ragam dsb) yang dibuat untuk menghasilkan sesuatu.

Sedangkan Pembelajaran merupakan suatu rangkaian kegiatan untuk memungkinkan terjadinya proses belajar yang dirancang, dilaksanakan dan dievaluasi secara sistematis agar dapat mencapai tujuan pembelajaran tersebut secara aktif, efektif dan inovatif.

Pada model pembelajaran menurut Zaini, model pembelajaran adalah pedoman berupa program atau petunjuk strategi mengajar yang dirancang untuk mencapai suatu tujuan pembelajaran. Pedoman itu memuat tangguangjawab guru dalam merencanakan, melaksanakan dan mengevaluasi kegiatan pembelajaran. Salah satu tujuan dari penggunaan model pembelajaran adalah untuk meningkatkan kemampuan siswa selama belajar.

Menurut Sukmasari Model pembelajaran adalah suatu rencana mengajar yang melibatkan pola pembelajaran tertentu. Dalam pola tersebut dapat terlihat kegiatan guru, 
siswa, sumber belajar yang digunakan di dalam mewujudkan kondisi belajar atau sistem lingkungan yang menyababkan terjadinya belajar pada siswa.

Dari berbagai macam pengertian diatas maka dapat diambil kesimpulan model pembelajaran adalah suatu pola yang dijadikan pedoman dalam startegi mengajar untuk mencapai suatu tujuan pembelajaran.

\section{B. PENGERTIAN PEMBELAJARAN}

Menurut undang-Undang Sistem Pendidikan Nasional No. 20 Tahun 2003 menyatakan pembelajaran adalah "proses interaksi peserta didik dengan pendidik dan sumber belajar pada suatu lingkungan belajar". Pembelajaran sebagai proses belajar yang dibangun oleh guru untuk mengembangkan kreatifitas berpikir yang dapat meningkatkan kemampuan berpikir siswa, serta dapat meningkatkan kemampuan mengkontruksikan pengetahuan baru sebagai upaya meningkatkan penguasaan yang baik terhadap materi pelajaran.

Menurut Gagne dan Briggs (1979:3) Pengertian pembelajaran adalah suatu sistem yang bertujuan untuk membantu proses belajar siswa, yang berisi serangkaian peristiwa yang dirancang, disusun sedemikian rupa untuk mempengaruhi dan mendukung terjadinya proses belajar siswa yang bersifat internal.

Sugandi, dkk (2004:9) Menyatakan bahwa pembelajaran terjemahan dari kata "instruction" yang berarti self instruction (dari internal) dan eksternal instructions (dari eksternal). Pembelajaran yang bersifat eksternal antara lain datang dari guru yang disebut teacing atau pengajaran. Dalam pembelajaran yang bersifat eksternal prinsip-prinsip belajar dengan sendirinya akan menjadi prinsip-prinsip pembelajaran.

Pengertian ini menggambarkan bahwa Pembelajaran merupakan aspek kegiatan manusia yang kompleks yang tidak sepenuhnya dapat dijelaskan. Pembelajaran secara simpel dapar diartikan sebagai produk interaksi berkelanjutan antara pengembangan dan pengalaman hidup. Pembelajaran dalam makna kompleks adalah usaha sadar dari seorang guru untuk membelajarkan siswanya "mengarahkan interaksi siswa dengan sumber lainnya" dalam rangkan mencapai tujuan yang diharapkan.

Menurut Sanjaya (2011:13-14) Pembelajaran merupakan suatu sistem yang kompleks yang keberhasilannya dapat dilihat dari dua aspek yaitu aspek produk dan aspek proses. Keberhasilan pembelajaran dilihat dari sisi produk adalah keberhasilan siswa mengenai hasil yang diperoleh dengan mengabaikan proses pembelajaran. Hal ini menunjukkan bahwa dalam pembelajaran diharapkan siswa benar-benar merasakan manfaat pembelajaran itu setelah ia mempelajarinya. 
Komalasari (2013:3) menambahkan bahwa Pembelajaran merupakan suatu sistem atau proses membelajarkan pembelajar yang direncanakan, dilaksanakan dan dievaluasi secara sistematis agar pembelajar dapat mencapai tujuan-tujuan pembelajaran secara efektif dan efesien. Pembelajaran merupakan sumber berupa visual maupun audiovisual yang dapat digunakan sebagai saluran alternatif pada komunikasi di dalam proses pembelajaran.

Berdasarkan kajian di atas, istilah pembelajaran yang digunakan dalam penelitian ini adalah suatu pembelajaran yang disusun secara sistematis yang digunakan guru dan siswa dalam pengajaran bahasa Indonesia di sekolah untuk mencapai tujuan yang diharapkan.

\section{MODEL PEMBELAJARAN}

Model pembelajaran merupakan kerangka konseptual atau pola suatu pembelajaran. Kerangka konseptual atau pola tersebut dirancang untuk melaksanakan suatu pembelajaran yang di dalamnya tercakup tujuan-tujuan pengajaran, tahap-tahap dalam kegiatan pembelajaran, lingkungan pembelajaran, dan pengelolaan kelas. Semua unsur tersebut disusun secara sistematis untuk mengorganisasikan pengalaman belajar dalam rangka mencapai tujuan pembelajaran. Rancangan ini menjadi pedoman guru dalam mempersiapkan dan melaksanakan kegiatan belajar mengajar. Model ini dibuat dengan tujuan untuk membantu guru dalam mengaplikasikan kurikulum, mengembangkan materi ajar, dan melaksanakan pembelajaran di kelas. Sebagaimana Brady (1985: 7) dalam Aunurrahman (2009: 146) mengemukakan bahwa model pembelajaran dapat diartikan sebagai blueprint yang dapat digunakan untuk membimbing guru di dalam mempersiapkan dan melaksanakan pembelajaran.

\section{KEARIFAN LOKAL}

Secara umum local wisdom (kearifan setempat) dapat dipahami sebagai gagasangagasan setempat (local) yang bersifat bijaksana, penuh kearifan, bernilai baik, yang tertanam dan diikuti oleh anggota masyarakatnya. Sedangkan, yang dimaksud kearifan budaya adalah seluruh usaha dan hasil usaha manusia atau masyarakat yang dilakukan dan ditujukan untuk memberikan makna manusiawi dan membuat tata kehidupan manusiawi pula. Dalam rangka memenuhi kebutuhan hidupnya, usaha dan hasil budaya manusia diarahkan untuk meningkatkan harkat dan nilai-nilai luhur kemanusiaan.

\section{E. METODE PENELITIAN}


Setiap penelitian memiliki pendekatan yang berbeda-beda, bergantung pada metode yang digunakan masing-masing. Pendekatan yang digunakan dalam tulisan ini adalah penelitian kualitatif deskriptif. Penelitian kualitatif merupakan penelitian yang bermaksud untuk memahami fenomena tentang apa yang dialami oleh subjek penelitian, misalnya perilaku, persepsi, motivasi, tindakan, dan lainlain. Pendekatan penelitian kualitatif ditentukan oleh karakter penelitian kualitatif, yang tentu berbeda dengan karakter penelitian kuantitatif.

Dilihat dari ruang lingkupnya, penelitian kualitatif dibagi ke dalam dua cakupan, yakni penelitian kepustakaan (library research) dan penelitian lapangan (field research). Penelitian kepustakaan mengandalkan data-data yang hampir sepenuhnya dari perpustakaan, sehingga penelitian ini lebih populer dikenal dengan penelitian kualitatif deskriptif kepustakaan atau penelitian bibliografis. Selain itu, penelitian kepustakaan sering juga diistilahkan dengan penelitian non-reaktif, karena sepenuhnya hanya mengandalkan data-data yang bersifat teoritis dan dokumentasi yang ada di perpustakaan. Sementara itu, penelitian lapangan mengandalkan data-datanya di lapangan (social setting) yang diperoleh melalui informan dan data-data dokumentasi yang berkaitan dengan subjek penelitian.

Penelitian pustaka atau studi pustaka tidak hanya sekadar urusan membaca dan mencatat literatur atau buku-buku. Penelitian pustaka merupakan rangkaian kegiatan yang berkenaan dengan metode pengumpulan data pustaka, membaca dan mencatat serta mengolah bahan penelitian. Adapun dalam tulisan ini, jenis penelitian yang digunakan adalah penelitian kualitatif deskriptif kepustakaan atau penelitian bibliografis, karena mengandalkan teori-teori dari buku sebagai literatur.

\section{F. HASIL DAN PEMBAHASAN}

\section{A. Model Pembelajaran Bahasa Dan Sastra Indonesia Berbasis Kearifan Lokal}

Dalam dunia pendidikan seringkali kita menemukan berbagai masalah dalam berbagai hal yang menyangkut tentang pengajaran, pembelajaran dan proses dalam suatu pembelajaran itu sendiri, salah satunya yaitu penggunaan metode pengajaran yang monoton dapat menjadian siswa sulit untuk menangkap berbagai informasi ataupun materi yang disampaikan. Baik pembelajaran secara indoor maupun outdoor. Guru pun sering tidak memperhatikan metode yang digunakan apakah metode tersebut sesuai dengan pembelajaran yang terkait atau tidak, sebagian guru juga sering menggunakan satu metode pembelajaran untuk semua mata pelajaran, yang akibatnya siswa sering tidak merespon apa yang 
disampaikan oleh guru. Untuk menunjang keberhasilan dalam suatu proses pembelajaran guru dan siswa dituntut untuk selalu aktif dalam suatu pembelajaran yang berlangsung, seringkali guru yang aktif dan siswanya pun tidak mempunyai feedback terhadap apa yang disampaikan oleh guru. Untuk membangun metode pembelajaran yang berbasis kearifan lokal guru dituntut untuk bisa memahami tingkat kemampuan siswa agar siswa dapat menumbuhkan sifat rasa percaya dirinya dan terdorong untuk mengikuti proses pembelajaran dengan baik.

Pelaksanaan model pembelajaran bahasa dan sastra Indonesia berbasis kearifan lokal memiliki pembelajaran yang menghubungkan media pembelajaran yang berupa contoh buku harian, tayangan power point untuk menjelaskan materi dan menghubungi toho atau anggota masyarakat dalam kearifan budaya lokal.

Kearifan budaya lokal selain memiliki nilai-nilai yang positif ternyata dapat membantu untuk meningkatkan kompetensi pembelajaran siswa yang negatif menjadi positif. Kompetensi pembelajaran meningkat disebabkan sumber inspirasi yang berasal dari kearifan budaya lokal lebih mudah dipahami dan telah dikenali oleh siswa.

Untuk menciptakan pembelajaran yang berbasis kearifan lokal pendidik harus mengetahui tentang hal-hal yang dapat menunjang keberhasilan dalam proses belajar salah satunya yaitu mengetahui budaya-budaya lokal khususnya pada budaya Sumatera Utara (Melayu Deli) dan sumber belajar. Jika dipahami secara rinci model pembelajaran dan sumber belajar itu berbeda pada segala sesuatu (benda, data, fakta, ide dll) yang bisa menimbulkan proses belajar yang memiliki keterkaitan dengan kebuayaan lokal.

Terdapat berbagai unsur-unsur model pembelajaran berbasis kearifan lokal khususnya pada budaya melayu yang harus dipahami yaitu :

1) Petunjuk belajar yaitu komponen utama yang meliputi petunjuk bagi pendidik maupun peserta didik yang didalamnya dijelaskan tentang bagaimana pendidik sebaiknya mengajarkan materi yang berkaitan kerarifan lokal kepada peserta didik dan sebagaiman pula peserta didik sebaiknya mempelajari materi yang ada dalam pembelajaran tersebut.

2) Kompetensi yang akan dicapai maksud dari komponen tersebut adalah kompetensi yang akan dicapai oleh siswa. Pendidik harus menjelaskan dan mencantumkan dalam pembelajaran yang sudah disusun dengan standart kompetensi, kompetensi dasar, maupun indikator pencapaian hasil belajar yang harus dikuasai peserta didik. 
3) Informasi pendukung merupakan berbagai informasi tambahan yang dapat melengkapi pembelajaran, sehingga peserta didik akan semakin mudah menguasai pengetahuan yang akan mereka peroleh.

4) Latihan-latihan merupakan suatu bentu tuga yang diberikan peserta didik untuk melatih kemampuan siswa setelah mempelajari pembelajaran yang berkaitan dengan kearifan lokal budaya khususnya pada budaya melayu deli.

5) Petunjuk kerja atau lembar kerja adalah suatu lembar atau beberapa lembar kertas yang berisi sejumlah langkah prosedural cara pelaksanaan aktivitas atau kegiatan tertentu yang harus dilakukan peserta didik berkaitan dengan praktik dan sebagainya.

6) Evaluasi dalam komponen evaluasi terdapat sejumlah pertanyaan yang ditujukan kepada peserta didik untuk mengukur seberapa jauh penguasaan kompetensi yang berhasil mereka kuasai setelah mengikuti proses pembelajaran.

\section{PENUTUP}

Model pembelajaran adalah suatu rencana mengajar yang melibatkan pola pembelajaran tertentu. Dalam pola tersebut dapat terlihat kegiatan guru, siswa, sumber belajar yang digunakan di dalam mewujudkan kondisi belajar atau sistem lingkungan yang menyababkan terjadinya belajar pada siswa.

Pembelajaran merupakan kombinasi yang tertata meliputi segala unsur manusiawi, perlengkapan, fasilitas, prosedur yang saling mempengaruhi dalam mencapai tujuan dari pembelajaran.

Kearifan budaya lokal khusunya pada budaya melayu deli selain memiliki nilai-nilai yang positif ternyata dapat membantu untuk meningkatkan kompetensi pembelajaran karakter siswa yang negatif menjadi positif. Guru meningkat kemampuan siswa disebabkan sumber inspirasi yang berasal dari kearifan budaya lokal lebih mudah dipahami dan telah dikenali oleh siswa sebelumnya.

\section{DAFTAR PUSTAKA}

Aunurrahman. 2009. Belajar dan Pembelajaran. Bandung: Alfabeta. BSNP. 2006. Kurikulum Bahasa Indonesia. Jakarta

Ghazali, A.Syakur. 2010. Pembelajaran Keterampilan Berbahasa dengan Pendekatan Komutatif Interaktif. Bandung: PT.Refika Aditama.

Guru Profesional: Implementasi Kurikulum Tingkat Satuan Pendidikan (KTSP) dan Sukses dalam Sertifikasi Guru. 
Sanjaya, Wina. 2011. Strategi Pembelajaran Berorientasi Standar Proses Pendidikan. Jakarta: Kencana.

Sunendar. 2011. Strategi Pembelajaran Bahasa. Bandung: PT. Remaja Rosdakarya.

Sayuti, Suminto A. 2009. Makalah yang disumbangkan untuk Pendidikan Kesadaran Bela Negara bagi Pemuda Tingkat Nasional Tahun 2009, Kementerian Negara Pemuda dan Olahraga bekerja sama dengan Departemen Pertahanan, 25 Maret 2009. 